\title{
All Vision No Substance; are Unmet Expectations a Key Factor in the Voluntary Turnover and Discharge of Enlisted Personnel in the Naval Service?
}

\section{Tony O’Regan}

\begin{abstract}
This article examines the early voluntary turnover of enlisted personnel within the Irish Naval Service. The purpose of the study is to explore current challenges facing the organisation regarding the retention of young, recently enlisted personnel. The paper adopts a qualitative research design with an interpretivist approach and draws on semistructured interviews undertaken with key respondents from the Irish Naval Service. The article explores different models for understanding the turnover process and makes recommendations with relevance for current and future policy. Key findings include the urgent need for the Irish Naval Service to develop a retention strategy for young enlisted personnel, and also the need for recruits to be made aware of the realities of life at sea before joining and before they are posted to sea. The paper identifies that, without significant change, the Naval Service may face an ongoing crisis regarding the retention of enlisted personnel.
\end{abstract}

This article examines early voluntary turnover of enlisted personnel in the Irish Naval Service. It examines the current challenges facing the organisation regarding retention of young new enlisted personnel and those who are in their first initial contract. Military organisations invest heavily in recruitment, selection and training. The loss of these workers, and associated corporate knowledge, is costly to the organisation, and while human resource (HR) planning can cater for the expected wastage in respect of recruitment, any unexpected wastage can be detrimental to the efficient provision of services and operational capability at sea.

The Irish Naval Service (INS) is the state's primary seagoing agency and is tasked with numerous roles in one the toughest environments in the world; the North Atlantic. An enlisted sailor can on average spend up to 180 days at sea each year, fulfilling the roles and tasks assigned to them by senior naval management, the Defence Forces (DF) and Government. To accomplish these roles a diverse, multi-skilled and dynamic workforce is needed. In the current climate the area of turnover and retention is something that necessitates meaningful attention as the INS is currently in the grip of a retention crisis. The fundamental principles of putting a ship to sea and the performance of Maritime Defence and Security Operations (MDSO) have been compromised by the haemorrhage of personnel from 
the organisation. This has led to what has been termed as a 'consolidation phase' and has forced the docking of two naval vessels indefinitely. Significant numbers of enlisted sailors have left the INS to take up jobs the private sector, a fact that has received extensive coverage in the Irish media (O'Riordan, 2019).

In 2015, the exodus was so substantial that high-ranking officials within the Defence Organisation commissioned the 'Work Climate Survey' in the Defence Forces (Irish Defence Forces, 2015). However, the report has not had the desired impact on retention proposals, and DF numbers remain in decline. This work is of significant interest to the INS as the voluntary turnover of young enlisted sailors has accelerated considerably, thus having a direct effect on the efficiency of the personnel remaining within the service. The resultant strain is being observed both on-board ship - in order to continue to meet the requirements of the job, and also ashore- where personnel on their shore rotation, having completed their required sea rotation, are required to spend increasing amounts of time at sea as reliefs.

For the military, reduced efficiency means less capability and lower readiness, with possible security implications for the long term (Hogue, 2006). More significantly, the numbers recruited are below those required to maintain the agreed strength of the INS. Thus, current retention issues are a key concern. The data collected and recommendations which stem from the research may inform the INS on the current issues for young enlisted personnel in the service, and provide discourse on methods of improving the rate of retention of young enlisted personnel in the future.

\section{Seamans Branch of the Naval Service}

In today's world the military must compete with corporate conglomerates to retain talented individuals and cannot offer the same career opportunities or financial rewards as multinational organisations. The INS is not immune to this trend, particularly since its staffing levels are maintained from voluntary enlisted personnel. These employees make up the three branches of the INS, logistics, engineering, and the executive or Seaman's Branch.

The Seaman's Branch of enlisted sailors are the heart of all Naval Ship operations and represent 15 percent of the overall establishment of personnel within the INS. They are the multitaskers of the fleet and are trained in multidiscipline evolutions. The day-to-day running of a ship can only be carried out successfully with a cohort of specifically trained personnel who operate on a 24-hour basis. They are tasked to steer the ship, carryout all deck evolutions, drive the boats in routine fishery and maritime drug interdiction operations, and complete all basic maintenance and ship husbandry on-board. They also hold responsibility for the general appearance of the ship and thus are tasked with most of the housekeeping on-board, both above and below decks. In many regards they are the vanguard of any ship.

Additionally, the Seamans Branch for many enlisted sailors is a means to completing the coveted naval divers' course and becoming a member of the elite diving team. Military dive training worldwide, and within the Irish Defence Forces, has the reputation of being one of the most physically and psychologically challenging courses available to enlisted personnel. Attrition rates on the diving course stand at a staggering 60 percent. Thus, with 44 percent of the Naval Service Diving Sections (NSDS) establishment made up of seamen it is vital that this section can attract a large pool of young sailors to apply for the diving course each year. Of the 10 vacancies available for seamen in the NSDS, only one is filled at present (2021). 
Furthermore, due to current crew shortages being experienced, Seamen's Branch is having greater difficulty in releasing seamen from seagoing duties to allow them to commence the 16-week diving course. From a ship captain's perspective, the importance of retention is just as evident. Retention of enlisted seamen has a direct consequence on bottom line- unit capability.

\section{PART ONE. Literature Review}

This review examines literature pertaining to the origin of turnover models, unfolding models, and the psychological contract. Analysing the key variables associated with these models has helped to contribute to the overall research as a means to explaining the concepts of the turnover process and underpins the fundamental factors of early turnover theories. The INS is struggling to retain its personnel, particularly general enlisted sailors who represent a substantial cohort of the service. Therefore, the aim of this analysis is to identify research into the validity of using retention theory in a military context to redefine the conceptual framework of turnover.

\section{Models of turnover}

Models of turnover are a means of incorporating knowledge gathered from studies of turnover behaviour to explain the process by which an employee decides to leave an organisation (Singh, 2015). They can be broken down into two categories; content models, which focus on the reasons "why" employees voluntarily left an organisation, and process models; "how" employees arrive at their decision to leave the organisation (Gauger, 2001). The term "turnover" is defined by Price $(1977$, p. 10) "as the ratio of the number of organisational members who have left and divided by the average number of people in that organisation during the period."

The origin of interest pertaining to turnover can be traced to Barnard's (1938) theory of Organisation Equilibrium, which states that a person will contribute to the organisation if properly incentivised. Additionally, perceived job desirability (equated with job satisfaction), and ease of movement (equated with job opportunities) are also recognised as key influences that affect employee turnover (Lee \& Mitchell, 1994). Barnard's work was contemporary in recognising incentives in organisational behaviour and was a forerunner for emerging theorists to develop early turnover models.

The evolution from Barnard's early work can be seen in March and Simon's (1958) initial turnover framework which laid the rudiments for further research and explains why so many models have been developed on studies of voluntary turnover (Singh, 2015). Their research enabled theorist William H. Mobley's initial work on Intermediate Linkage retention.

Mobley's (1977) Intermediate Linkage retention model proposed that job dissatisfaction leads to thoughts of leaving. Two vital components of Mobley's model posit that job attitudes, or job dissatisfaction are directly linked to thoughts of leaving. The dynamics associated with these factors are indirectly linked to the actual turnover process (Mowday, et al. 1984). Notwithstanding, as an initial turnover model, it identifies the connection between turnover rates to job attitudes, such as, job satisfaction and organisational commitment (Mobley, 1977).

Mobley's (1977) initial work relating to job satisfaction and organisational commitment has received much attention, and has contributed significantly to the growth of turnover 
literature, in particular, the importance of job attitudes in turnover models (Allen, Shore \& Griffeth, 2003; Capon; Chernyshenko \& Stark, 2004). Job attitudes are multifaceted in their composition and consist of cognitive, affective, and performance elements. However, of these multidimensional factors, two important attitudes are job satisfaction and organisational commitment which will be examined in the following section.

\section{Job satisfaction}

According to Judge and Mueller (2012, p. 344), "job attitudes are evaluations of one's job that express one's feelings toward, beliefs about, and attachment to one's job". Attitudes focus on the crucial components identified as important antecedents to turnover, which are broken down into job satisfaction and job opportunity. Job satisfaction is defined as how much employees like their job (Price \& Muller, 1986). Agho, Mueller and Price (1993) building on the Price Mueller Job Satisfaction Model recognised that to comprehend the aspects influencing worker satisfaction, the collective effects of the following must be considered:

- $\quad$ Environment (job opportunity)

- Job characteristics (workload, distributive justice)

- $\quad$ Personality traits and values of the employees (work motivation)

These factors are important when considering job satisfaction as they represent a combination of positive or negative feelings that workers have towards their work and the organisation.

\section{Environment - Job Opportunity}

The concept of desirability, and ease of movement, has been discussed as variables included in early models of turnover probability. In most current models of turnover, perceived job prospects are comprised amongst the contributors of turnover behaviour. Examples of this can be seen in Cook, et al. (2007) and Zimmermans'(2019), work synthesizing models of employee turnover. Conversely, Gerhart (1990) established that unemployment rate was a direct predictor of the level of turnover.

Carsten and Spector (1987) proposed that employment discontent is more likely to lead to turnover when the unemployment rate is comparatively low. Agho, et al. (1993), therefore suggesting that it is expected that dissatisfaction decreases during times of high unemployment. Therefore, it can be surmised that, at present in Ireland, it could be expected that job satisfaction levels would drop due to high employment levels nationally, leading to a decrease in retention rates.

\section{Job Characteristics}

An individual's perceptions of job and organisational characteristics are influential factors in their developmental process with respects to turnover. Job and organisational characteristics cover extensive factors relating to that person's perceptions through quality of life (Sumer \& Van de Ven, 2007). Two distinct areas of research discussed are compensation and workload (instrumental), and leader-member relations and work group cohesion (non-instrumental). Both elements will be discussed further within the psychological contract.

However, it is sufficient to say that workload, job pressure, job related stress, pay grade, and the perception of distributive justice (equating to fairness) can influence both job 
satisfaction, and organisational commitment, and are well established precursors of turnover in general (Griffeth \& Hom, 2001).

\section{Person-Environment Fit}

Research conducted into employee traits and values, and the effects on job satisfaction leading to turnover intentions, have been categorised within the person environment fit literature.

Schneider's (1987, p. 437) attraction-selection-attrition model states that "individuals are attracted to and stay with organisations that suit their personality characteristics". One element termed job embeddedness has unearthed voluntary turnover predictions by looking beyond organisational commitment and job satisfaction (Mitchell, et al. 2001). According to Sumer and Van de Ven (2007), job embeddedness refers to an employee's:

- $\quad$ Relationship with other individuals within the organisation

- $\quad$ Perceptions of his/her fit within the organisation

- Values congruence

Therefore, the fit of an employee's personal values, "values congruence", and their organisational commitment additionally contributes to job satisfaction, and overall turnover. Sumer and Van de Ven (2007) posit that "these forms of fit are expected to be critical in the military turnover process".

\section{Organisational commitment}

Organisational commitment as an attitude, is defined as "an individual's psychological bond with the organisation, as represented by an affective attachment to the organization, a feeling of loyalty toward it, and an intention to remain as part of it" (Judge \& Mueller, 2012, p. 343). The effect that organisational commitment has on turnover intentions has been widely acknowledged by Griffeth, Hom and Gaertner (2000, p. 480) who posited that "organisational commitment predicted turnover better than job satisfaction". The explanation of organisational commitment that is most cited is that of Meyer and Allen (1997). They proposed that organisational commitment is developed by an individual based on the combined effectiveness of affective commitment, continuance commitment, and normative commitment:

- Affective commitment corresponds to the individual's emotional attachment and participation in their organisation and is the "want to" factor of commitment.

- Continuance commitment is the acknowledgement of the costs borne by the individual on parting with the organisation, and is associated with the "need to" factor of commitment, and finally,

- Normative commitment is the person's feeling of moral responsibility to stay with the organisation and is the "ought to" aspect of their organisational commitment.

Of the theoretical three-component model, affective commitment generally has the highest validity in predicting organisational behaviours such as job performance. Job attitudes are central to turnover prediction as most individuals spend many of their waking hours at work, where work is fundamental to individuals' identities, and job attitudes have important consequences. Models of voluntary turnover have conventionally been attitudecentred, aiming to capture the psychological processes involved in voluntary turnover. However, traditional turnover models fail to consider the human factor and to fully account 
for turnover behaviour that can develop because of unexpected life events. This type of turnover can be explained in the Unfolding Model.

\section{Unfolding model of turnover}

In response to the traditional push-pull turnover models suggested by Mobley (1977) and Steers \& Mowday (1981), Lee and Mitchell (1994) propose a theory of "unfolding model of turnover". Turnover may occur with very little deliberation, which consecutively can account for some of the spur-of-the-moment choices made by disgruntled employees. Holt, et al. (2007), contend that these are often disregarded in previous studies. The model is based on Beach's (1990) Image theory and attempts to comprehend the turnover decision process made by workforces (Singh, 2015). However, these decisions may be rash, or spur-of-themoment, caused by life changing shocks.

\section{Shocks}

Lee and Mitchell's (1994) "unfolding model of voluntary turnover" fundamentally states that unexpected life events, termed shocks, can be a source of voluntary turnover. These occur more frequently than the accumulation of job dissatisfaction, and are relevant because turnover is frequently triggered by a precipitating event which adds to the complexity experienced by the individual (Holtom, et al. 2005).

Lee and Mitchell (1994, p. 60) define a shock to the system as "a very distinguishable event that push employees toward deliberate judgements about their jobs and perhaps to voluntarily quit". Life shocks, such as, the first time away from loved ones, being newly married, or becoming a parent, can have critical influences on a person's decision-making process. Often these unexpected life events can trigger a rash decision in an employee's mind. The unfolding model suggests that shock can be the precursor to turnover within an individual's decision path.

- $\quad$ Path 1, life shocks for example, such as marriage or pregnancy can be the trigger for a pre-determined plan or script, where very little thought is given to alternative job consideration or job satisfaction and values are questioned in the employee's mind. Therefore, job satisfaction is immaterial in the decision to leave.

- $\quad$ Path 2, a negative shock like being passed over for promotion or the offer of a muchanticipated job, and or, a major company take over, causes the employee to question their attachment to the organisation. In this path, job satisfaction levels prior to the shocking event can be irrelevant and the person could leave without searching for alternatives.

- $\quad$ Path 3 is given much more deliberation as the results from the shock can be either positive, negative, or neutral. Unlike in path 1 or path 2 , this shock could initiate a search for alternatives with comparisons made between the job offer and the current job. Thus, job satisfaction and organisational commitment are considered in the turnover decision.

- $\quad$ Path 4, in this route to turnover, non-compatibility to fit in with the organisation results in unhappiness and less commitment. This in turn, leads to leaving with or without searching for another course of action or alternative (Donnelly \& Quirin, 2006).

In summary, shocks are diverse in nature, and a significant precursor to employee turnover. What is also an important consideration when discussing the nature of shocks are the underlying effects, they may have on the employee psychological contract. 


\section{The psychological contract}

Researchers have endeavoured to operationalise expectations in occupational relationships by scrutinising the employees' psychological contract, or their views about the terms and conditions of the relationship between themselves and the organisation (Rousseau, 1989). During their employment, the psychological contract is a continuous process that is negotiated throughout an employee's stay in an organisation (Deepa, 2016).

Schein (1980, p. 22) describes "the psychological contract as an unwritten set of expectations operating at all times between every member of an organisation, the various managers and other employees". Morrison and Robinson (1997, p. 229) further posit that the psychological contract is "an employee's beliefs about the reciprocal obligations between that employee and his or her organisation, where these obligations are based on perceived promises and are not necessarily recognised by agents of the organisation. At its core, the psychological contract considers the expectations of the individual, what they expect to give the organisation, and what they look for in return.

Furthermore, (Rousseau, 1989, p. 123) suggests that the psychological contract is "an individual's beliefs regarding the terms and conditions of a reciprocal exchange agreement between that person and another party". As alluded to earlier, the psychological contract can be divided into different contract types, and this will now be examined.

\section{Contract types}

Psychological contracts can be distinguished by two main themes, transactional and relational. Both contact types are an unwritten set of 'promises' or 'expectations' between the parties in an employment relationship. In transactional contracts, workforces do not anticipate an enduring relationship with their employer, alternatively viewing their employment as a transaction. For example, long hours and extra work are provided in exchange for high pay, training, and development (Rousseau \& Wade-Benzoni, 1995).

In today's workplace, transactional, or monetary rewards, are clearly visible and involve reward for specific forms of employment (McDermott, et al. 2013). Namely, "a fair days pay, for a fair day's work", where a clear transaction occurs. Transactional contracts tend to be for short durations, with very few, if any, obligations, and loyalty to the organisation. Rousseau and Robinson (1994) posit that transactional contracts involve highly explicit exchanges, which take place over a predetermined period. However, in the military context, competitive resources (when no financial reward available) can play a crucial part in the transactional psychological contract (Heffernan \& Rochford, 2017). These may be in the form of promotion, training courses, or overseas deployment.

Alternatively, relational contracts depend on the socio-emotional resources in which the employees have a long-term and widely defined relationship with infinite application. According to Rousseau, (1989, p. 121) "a relational contract is dynamic and subject to change". Fundamentally, it's about the people and a safe working environment within the organisation, and the contracts are based on trust, fairness, and good faith (Deely, 2014). Heffernan and Rochford (2017, p. 101) posit that "such relational agreements also tend to include employee development and future growth opportunities in anticipation of valueadding contributions to the employer over time or employability on the external job market". However, the reason relational contracts succeed is that the employees are ambitious, and 
emotionally committed to the organisation. These commitment trends are referred to as Organisational Citizen Behaviour.

\section{Social exchange theory and organisational citizen behaviour}

Organisational citizen behaviour (OCB) theory suggests that human interactions can be perceived as transactions and is consequently in line with the intellectual approach (Kabasakal, et al. 2011). Moreover, Will (2012, p. 288), further posits that "social exchange theory refers to the voluntary actions of individuals that are driven by the returns they are expected to bring". Therefore, employees are more likely to be emotionally committed to the organisation because it has been seen to keep its promises (Tekleab \& Chiaburu, 2011). This is particularly important when considered in the context of the unique nature of a military serviceperson's obligations. The emergence of OCB is synonymous with social exchange theory and dates back to the early work of Barnard, when he identified that people were inclined to contribute supportive dynamics to achieve organisational objectives (Gurbuz, 2009). OCB has been redefined since the phenomenon was observed by Organ (1988) in the late 1980s, but the concept remains the same.

Therefore, for the purpose of this research, OCBs can be defined as "behaviours sought after but not formally prescribed and not explicitly rewarded by an organisation" (Will, 2012, p. 288). OCB is discretionary, and is therefore, easily explained in colloquial terms as, going the extra mile, or, good soldier syndrome (Zhang, 2011). OCB is the additional work undertaken by an employee that is not an express requirement of their job description.

When reviewing OCB in organisations, Sechudi (2014) posits that there are five assorted categories of positive employee behaviour that should be considered: civic virtue, sportsmanship, courtesy, altruism, and conscientiousness. Many of these categories can be linked to the INS, as military organisations would describe such concepts as doing more than just the minimum, whilst paying attention to detail. The advantages associated with OCB have commonly been linked with organisational effectiveness through the accomplishment of formal, or recognised goals (Sechudi, 2014). Miles, et al. (2002) argue that individuals occasionally will complete more than what is expected of them, which helps the organisation in boosting its efficiency.

However, OCB behaviours can be linked to negative relationships with certain perceptions. Deepa (2016) observed that individuals' expectations of being treated fairly, and receiving in return what they delivered to the organisational success, is a factor that defines the psychological contract. Therefore, workers that are more susceptible to stress, or feel taken advantage of, as a result of engaging in $\mathrm{OCB}$, may tend to engage in role conflict, role uncertainty, and role burden (Sechudi, 2014). When an employee believes that there is a breach in the psychological contract then they are less likely to engage in OCB.

\section{Psychological contract breach}

Psychological contracts are perceptual and complex in nature and when individuals observe or identify what they believe to be a breach in the psychological contract, then it can lead to substantial variations in work attitudes and behaviours. Research by Heffernan and Rochford (2017) highlighted the undesirable effect such instances can have on almost all work-related outcomes. The psychological contract is breached "when one party in a relationship perceives another to have failed to fulfil promised obligations" (Robinson \& Rousseau, 1994, p. 246). 
Empirical evidence proposes that psychological contract violation is significantly related to turnover intentions (Robinson and Rousseau, 1994). A perceived breach of the psychological contract can have a detrimental effect on an employee's wellbeing. These factors may lead to anxiety, depression, and lack of morale, added with an increased cynicism in approaches concerning the organisation (Johnson \& O'Leary-Kelly, 2003). Morale, also known as esprit de corps, is the ability of a military member, in this case the sailors of the NS, to sustain belief in an institution, particularly in the face of hardship.

Research by the United States Naval Institute has shown morale is a key influencer and feeds into the mentality of a ship's company (Tyler, 2016). The ship, and by extension, its crew, are considered an extended family, where shipmates spend a considerable time living and working in close quarter environments, where a social network develops.

Recent personnel shortages in the INS have had a severe impact on the morale of the sea going crews (O'Riordan, 2019). Sailors depend on their shipmates, particularly in their social network, or during early socialisation during the evolution, and formation of their own psychological contract. This social network of shipmates is available when there is a perceived contract breach, or when trying to cope with situations such as deep-seated change, or organisational crises (Krackhardt, 1992). Understanding the dynamics that are at the core of employee psychological contracts is central for various reasons in relation to social networks (Heffernan \& Rochford, 2017).

The use of social networks to communicate informal information pertinent to the organisation has a direct bearing within the psychological contract, and can produce considerable benefits in the form of high quality of work. However, Robinson and Rousseau (1994) contend that, poor-communication that may lead to uncertainty, and, or, the inability to decipher information through the informal network can lead to confusion where individual, or organisational efforts, remain unfulfilled. This breaks the social network and certain bonds shipmates have with each other, thus having a negative impact on military turnover.

\section{Military Turnover}

Current thinking pertaining to military turnover is influenced by civilian theories of turnover and is defined as "a scenario in which military personnel leave or withdraw their services from military organisations" (Hosek \& Totten, 2002, p. 154). Within the global domain, the issue of military retention has received a great deal of empirical attention as military establishments are struggling to compete with the civilian sector to offer the same career prospects (Weiss, et al., 2003). Voluntary turnover models have conservatively remained attitude-centric, aiming to capture the psychological processes involved in voluntary turnover (Sumer \& Van de Ven, 2007).

As discussed, job-related attitudes, such as job satisfaction and organisational commitment, have the ability to influence turnover through a rational process, such as, thinking about quitting, and turnover intentions. Whilst these are important factors relating to turnover in civilian organisations, they will now be examined in a military context. However, as significant as these factors are, additional key factors such as met expectations, quality of life concerns, and the role of shocks in the military will be discussed.

\section{Job attitudes in the Military}

Various studies have been undertaken on the relevance of turnover research in the military (Van de Ven, 2001; Capon, et al. 2004). Analysis of the models relating to military retention 
identified that they utilise proximal, mediating, and distal factors that affect military turnover (Sumer \& Van de Ven, 2007).

- $\quad$ Proximal factors - Defined as turnover intentions, unemployment rate, and shocks.

- Mediating factors - Defined as quality of life concerns, work attitudes, job satisfaction, continuance, and affective commitment.

- Distal factors - Defined as job and organisational characteristics and perceived job alternatives.

These studies have established the effectiveness of theoretical research, identifying the importance of work satisfaction and organisational commitment on turnover intentions, and in attempting to predict retention in the military.

Job Satisfaction and Organisational Commitment in the Military

Organisational values are the principles and expectations shared by members of an organisation. The INS has been built on the cornerstone of military tradition. This provides a very strong and unambiguous organisational culture that differentiates itself from civilian organisations (Godlewski \& Kline, 2012).

Research by Schreurs and Lescreve (2001), Sumer and Van de Ven (2001), and Capon, et al. (2004), all identified and acknowledged that a military model of turnover must incorporate the unique nature of service life. In examining military service as a distinct career profession, one is duty-bound to recognise that the nature of service life distinguishes itself from what is commonly termed in the DF as civilian life. Bryce (2009) describes this phenomenon as the greater sacrifices a serving member will make once they have committed to serve their country.

The work of Capon, et al. (2004) confirms that there is merit in applying civilian retention theories to the military, but that these models need to be adapted to military life. Their research established that job satisfaction, and organisational commitment, are the greatest predictors of intentions to remain.

\section{Met expectations and the psychological contract}

The role of job characteristics, and met expectations, in a military context may be particularly beneficial in understanding turnover in the INS, and merit inclusion in any future retention strategy. Warn (1994) contends that commitment in the military is developed through training, which is designed to promote esprit de corps and morale, and will engender feelings of loyalty that will affect an individual when they are thinking of leaving.

Van de Ven (2004) posits that during initial training, in the first three to six months after enlisting in the military, a basic psychological contract between the recruit, and the organisation, will be developed. Recruits' initial perceptions will be categorised by high expectations toward the organisation, and lower expectations of themselves Rousseau (1995). During advancement within the organisation, they will adjust their expectations and awareness in line with reality. In a civilian environment, a newcomer's perception of organisational expectations will wane during the period of the initial months in their jobs, while the awareness of their own expectations will increase (Rousseau, 1995).

However, studies carried out on newly inducted recruits in the British Army by Thomas and Anderson (1998), indicate a significant increase in expectations. They identify a possible 
danger in this, proposing that, military organisations must attend to recruits psychological contract to ensure a realistic expectation is developed. They contend that managing realistic expectations within the psychological contract may prevent shocks triggered when enlisted personnel are exposed to the reality of military life.

\section{Organisational characteristics and personal traits}

Previous studies by Capon, et al. (2007) and Sumer (2004), highlighted the role of organisational characteristics, and personal characteristics, as distal predictors of retention with direct influence over job satisfaction and organisational commitment.

Rousseau (1995) further argues in relation to the psychological contract that, a shift has developed from traditional employment relations, characterised by "relational" contracts between employees and employers, toward transactional relationships or "new deals". This is due to fluctuating demands for labour and increased flexibility in the workforce (Van De Ven, 2003).

Rousseau's research proposes that transactional relationships, stemming from short term contracts, result in narrow involvement in the organisation, lower levels of organisational commitment, and increased turnover. This is relevant to the INS in terms of long-term careers, where poor pay and conditions have led to a high volume of turnover within the individual's initial five-year contract, as the individual perceives there has been a negative impact on their quality of life.

\section{Quality of life}

Quality of life (QOL) is defined as a person's total sense of comfort cultivated by his or her emotional state regarding certain life perceptions, combining living standards, their relationship status, number of children, and their health and well-being (Sumer \& Van de Ven, 2007). This was based on previous research completed by Kerce (1995) in the United States Marine Corps (USMC), and Dowden (2000) in the Canadian Armed Forces (CAF)

Sumer (2004) proposed a model of military turnover which focuses on QOL and the effect that it has on both organisational commitment and job satisfaction. He highlights the impact that personal dispositions have on QOL perceptions.

The most significant research into a military model of turnover has been carried out in the United States and it is specifically related to the navy where it incorporates the previously un-researched issue of shipboard life. Britt (1998), and Britt and Adler (1999), indicated that challenging weather conditions, prolonged working periods, and separation from a spouse or partner, coupled with an inability to contact family members when deployed at sea places an extra burden on an individual's QOL. The acknowledgement that working in the navy means living a qualitatively different way of life, has a significant impact on the design of the model. The resultant observation identifies that if the QOL issues that affect retention intent can be correctly identified, a strategic plan can be implemented to address the most significant issues with a view to improving overall retention.

\section{Role of shocks in the military}

Schwerin, et al. (2006) and Sumer, (2004) emphasised the significant impact in any model of military turnover that life at sea has on both work life and family life factors involved in military turnover. They suggest that when sailors proceed to sea, it impacts on in their quality of life, and this is a key indicator in retention and turnover models. Their study was successful, 
and the significance of their research findings for militaries, and in particular, navies worldwide, is that it proves that non-work factors best predict intention to remain, although this cannot overshadow that work factors also have significant impact on organisational commitment.

This research cites Ajzen's Theory of Planned Behaviour (Ajzen, 1985), which focuses on the belief that positive perceptions promote positive attitudes towards positive outcomes, or vice versa, and that these behavioural intentions are formed over a period of time. However, as mentioned previously and congruent with the "unfolding model of voluntary turnover", unforeseen life events, known as shocks, can cause voluntary turnover. Sumer and Van de Ven (2007) suggest that shocks are a key factor in the military turnover process. Nonetheless, further academic studies are essential to ascertain the model of turnover that is synonymous with shocks in the military domain.

Conversely, Holt, et al. (2007) suggest that the Lee and Mitchell's (1994) Model of Unfolding Turnover could offer an explanation why military personnel depart the INS following the birth of a child, or on completion of a contract. They propose that these shocks may result in a pre-existing plan to leave the organisation in the event of such a shock. Thus, research into the effects of shock may assist the organisation to develop retention strategies to address potential shocks, such as, the introduction of flexible work schedules. Consequently, the role of shocks is a factor that should be investigated prior to development of a proposed retention model into the INS.

The above review of relevant published literature was to examine various models of employee turnover and to investigate their applicability to the military to assess the feasibility of applying a model to the INS in order to address retention issues. The development of turnover models has progressed considerably from the early work of March and Simon the 1950s. Mobley's contributions in the late 1970s emphasised the impact of job satisfaction to turnover and remains the foundation of the majority of the models reviewed. The initial foundation models have become more complex as time has evolved, and additional research has identified the impact that various internal and external influences have on both, the individual, and the organisation, in relation to turnover intentions.

The applicability of turnover and retention models that have transitioned from civilian organisations to military organisations has been acknowledged, with the caveat that there is an inevitability to adapt these models in order to consider the culture, and way of life in the military. The influence of the psychological contract and associated contraventions, met expectations, and QOL issues, on the decision to remain in the military has been acknowledged in various models, both proven and conceptual, and this is of importance to the application of any models to the INS. The reality of life at sea in relation to the INS is shown to impact on the intent of an individual to remain, from both a work and non-work perspective, and this will need to be addressed in any strategic plan implemented to tackle retention issues (Schwerin, et al. 2006).

The literature suggests strong correlation between the development of retention strategies and benefit to an organisation, such as the INS, and there are numerous retention models which could be tailored to suit the specific requirements of the INS. However, the relevance lies in the intricacies regarding shocks, work related practices, and work life balance, because of the potential effects they have in relation to military turnover. The literature pertaining to military turnover suggests complexity but also the importance of 
individual factors outside of job attitudes affecting military turnover (Sumer \& Van de Ven, 2007).

Grounded in the review, the role of shocks is expected to play a significant role in military turnover. Shocks can originate from organisational, or job dissatisfaction. However, the category of shock pertaining to military members has been exposed as generic when dealing with military turnover. Studies are required to detect the types of initiating life events that may be a factor in military turnover. Thus, this has the ability for Senior Officers to plan for intervention and prediction of turnover (Sumer \& Van de Ven, 2007).

Likewise, Schreurs and Lescreve (2001), in their study on the role of information provision in bridging the gap between an individual's expectation and reality. This supports Thomas and Anderson's (1998) research, suggesting that use of the realistic job preview (RJP), intended to deliver new or potential recruits with truthful expectations of the organisation allowing a realistic psychological contract to develop, has proven a useful method in reducing early voluntary employee turnover. This aspect may be of specific interest within the INS, where following the cocooned environment of initial and branch training ashore, INS personnel are exposed to reality of life at sea.

Finally, under QOL, this research poses the question, does personal life quality affect an individual's work satisfaction? (Wilcove, et al. 2003) The bottom-up or top-down modelling methodology offers an effective way to explore QOL. However, these models necessitate personality data that are not collected by the INS.

\section{PART TWO. Methodology}

In order to explore this question and to gather data indicative of the INS, a qualitative approach was adopted to garner INS data (Ryan \& Walsh, 2015) and provided a deeper understanding of the topic as it was relevant to those serving within the INS

For research purposes the process of data collection was through semi structured interviews allowing for this qualitative data to be analysed through thematic coding (Gibbs, 2007). In order to gain an organisational perspective of retention within the INS, it was decided to interview the Officer in Charge (OiC) of the Personnel Management Section (PMS) and the Senior Non-Commissioned Officer (NCO) within the Seamen's Branch, who maintains direct influence on all matters concerning retention strategy, personnel support and development opportunities for young, enlisted personnel serving within the branch. The research was based on an open demographic of enlisted personnel, and therefore, had no gender bias between serving men and women.

Sampling was conducted randomly by choosing four seagoing operational units. Eight able rates volunteered to be interviewed and the only specific requirement was that they were on their first rotation at sea. To maintain their anonymity, each interviewee was coded AS1-AS8. Table 3.1 below denotes the interviewees by code. Their age range was between 18-26. Surprisingly, there were no female candidates nor a female perspective, which may have altered the findings when consideration is given to matters of maternity rights, childcare and the QOL with regards to time spent at sea. However, given that this research primarily focuses on new entrants on their first sea rotation, it is unlikely to impact on the findings. 


\begin{tabular}{|c|c|c|c|}
\hline DENOTATION & GENDER & UNIT & FIRST SEA ROTATION \\
\hline Able Seaman 1 AS1 & Male & L.E. CIARA & Yes \\
\hline Able Seaman 2 AS2 & Male & L.E. CIARA & Yes \\
\hline Able Seaman 3 AS3 & Male & L.E. JAMES JOYCE & Yes \\
\hline Able Seaman 4 AS4 & Male & L.E. JAMES JOYCE & Yes \\
\hline Able Seaman 5 AS5 & Male & L.E.W.B. YATES & Yes \\
\hline Able Seaman 6 AS6 & Male & L.E. W.B. YATES & Yes \\
\hline Able Seaman 7 AS7 & Male & L.E. SAMUEL BECKETT & Yes \\
\hline Able Seaman 8 AS8 & Male & L.E. SAMUEL BECKETT & Yes \\
\hline
\end{tabular}

Table 3.1 Criteria Denoting Interviewees

\section{Semi Structured interviews}

The benefits associated with the use of semi-structured interviews, is that the process provides a degree of flexibility with the potential to alter the line of questioning should they require further exploration. Thus, this would provide the best method to gain understanding of the experiences and beliefs of the interviewee. The questions asked drew on their experiences having served on board ships during the retention crisis.

As with all research, there were limitations and time was the main limitation for this research. All the respondents, except for two participants, are currently serving on-board a ship. Due to the operational requirements of the ships only personnel from four of the eight ships were a part of the research. Initially it was intended to interview individuals who had left the organisation, but met the criteria, but due to the geographical implications of interviewing people across Ireland, this proved impracticable. Thus, it was decided to interview personnel still serving, and on-board ships.

In the conduct of the semi-structured interviews, it was necessary to interview the Senior Officer involved in recruitment, and the Senior NCO who is the branch head. The fact that the interviewees had different experiences added to the depth of information. This also shaped an acute awareness that the findings from the research could have consequences that may affect the reputation of the INS, individuals within the organisation, and bring embarrassment and unwanted publicity to the organisation, and those who work in it. Consideration was also given to the effects on participants, particularly as the shifting of the lens was now focusing on turnover and retention whilst conscious that a certain line of questioning could potentially encourage them to leave the organisation.

\section{PART THREE. Research Findings}

This paper examines issues regarding early voluntary turnover of enlisted personnel within the Seamen's Branch of the Naval Service. A review of the literature identified and explored turnover theory in civilian settings, established the validity of using turnover research in a military environment and established the pathway deemed best fit for use in structuring research into the reasons for an acceleration of early voluntary turnover in the Naval Service at present. 
However, from an examination of turnover figures in the Naval Service in 2019, initial research has indicated a high level of turnover in the two years after enlisted personnel's initial posting to sea, following completion of initial, and branch specific training.

\begin{tabular}{|c|c|c|c|c|c|c|c|c|c|c|c|c|}
\hline & Seaman & Mech & Comms & Supply & ERA & HA & EA & RRT & Cook & SBA & Trainee & TOTAL \\
\hline wo & & & & & 1 & & & & & & & 1 \\
\hline SCPO & & & & 1 & 2 & & & & & & & 3 \\
\hline СРO & 3 & 1 & & & 4 & 1 & & & & & & 9 \\
\hline SPO & & & & 1 & & & & & & & & 1 \\
\hline PO & & 4 & 2 & & 7 & 2 & 2 & 2 & 3 & & & 22 \\
\hline L/S & 10 & 2 & 2 & & & & & 1 & 1 & & & 16 \\
\hline $\mathrm{A} / \mathrm{B}$ & 37 & 9 & 7 & 8 & & & & & 1 & 1 & & 63 \\
\hline PROG & & & & & & & & 3 & & & & \\
\hline Recruit & & & & & & & & & & & 9 & 9 \\
\hline Cadet & & & & & & & & & & & 2 & 2 \\
\hline TOTAL & 50 & 16 & 11 & 10 & 14 & 3 & 2 & 6 & 5 & 1 & 11 & 129 \\
\hline
\end{tabular}

Fig 4.1 NS Enlisted Personnel Turnover Figures 2019

Intentions to join a military organisation like the Naval Service are formed by attitudes and expectations and are based on a decision about whether starting in that career or joining that organisation will result in desired outcomes (Ford, et al. 2013). Many recruits enlisted in the Naval Service face challenges that they must come to terms with, such as, social transition to the military way of life, and in particular, the culture shock.

The primary data gathered through a series of semi-structured interviews with enlisted personnel serving at sea on-board ship in the Seamen's Branch and the senior Officer and Warrant Officer serving within the Naval Service with either direct control or influence on HR functions within the Seamen's Branch provides a valuable insight into the experiences of those interviewed. The data gathered provided raw material to help answer the primary research question, are unmet expectations a key factor in voluntary turnover and early discharge of enlisted personnel in the Irish Naval Service?

Each interview sought to establish the following:

- Where the interviewees had developed their perceptions of DF culture prior to enlisting.

- The role the organisation's PR campaign played in the development of initial expectations.

- Whether the initial expectations which attracted these individuals to the organisation were met.

From an early stage in the field research, it became evident that challenges facing the organisation regarding the psychological contract and meeting expectations arise at two distinct phases during new entry personnel's initial few months in the INS. The first stage was when joining the organisation, with the second stage taking place when newly qualified personnel proceed to sea for the first time.

\section{Joining the organisation}


It has been identified that the basis of this psychological contract between the INS and a potential recruit stems from two sources, the recruit's interaction with INS personnel, and the recruit's perceptions of DF culture (Van De Ven, 2004). Naval instructors who hold the characteristics required for recruit training are only involved in the initial training of recruits. Thus, regarding the new recruit's interaction with INS, this initial experience and their initial perception is vitally important in identifying and meeting expectations.

The core image being sold is the idea of "Strengthen the Nation" promulgated through the national media and forming the key message of DF recruitment over the last number of years. Public expectations might be along the lines of 'Heartbreak Ridge' or 'Full Metal Jacket', which portray recruit training scenes where young people are brought together into a strict military environment, where the highest discipline is required. Daily uniform and equipment inspections, learning new skills such as firing weapons and basic military parade drills, and generally pushing people to their physical and mental boundaries is the expectation of all. A strict regime where recruit's time is actively managed with limited opportunities to visit home is expected. It would be expected that this image is strengthened during the recruit intake process by INS personnel making specific promises to the potential recruits about what life in recruits will be like, providing documentation and enforcing this image (Feldman, 1977).

However, evidence from the interviews suggest that this was not the case. The level of information passed to the potential recruits pre-enlistment appears limited. When asked where the interviewees had gained most of their information forming their expectations of recruits, all mentioned other sources outside of the recruitment process. All mentioned family and friends within the DF, or time served within the Reserve Defence Forces (RDF). Moreover, when asked about reference material, many stated that the information received or available on the Irish Defence Force website (www.military.ie) was of limited benefit. Many struggled to understand terms and conditions regarding pay through the information provided on the website.

Able Seaman 1 (AS1) described how his time as a DF reservist had helped prepare him for the interview process as he previously knew "nothing about the Navy". However, his RDF experience had given him a realistic expectation of what recruit training entailed. He elaborated on this stating;

When I was 17, I joined the reserves, So, I kind of wanted to dip the toe into the water for real, see what it was like. Being more mechanically minded and the Navy have ships that are powered by engines, I'll try that and see how it goes.

AS2 who was on his first rotation to sea had gathered very little information with regards to recruitment saying:

So yeah, I had no preconceptions coming in. Only information I had picked up seeing the army in training like that. I had no idea, like, whether or not you'd be on a ship during training.

However, as a positive recruitment tool, the Serving members of the INS have represented the organisation professionally when dealing with members of the public. AS4, an ex-fisherman, described how he had witnessed the work of the Naval Diving team first- 
hand during a search operation off the coast of County Mayo which was a deliberating factor to make him want to enlist:

I think that a reason was the work that the Naval Divers do. A mate of mine went missing, so they were called down. I saw the work they were doing searching for him and its one of the reasons why I joined like, so I think the Naval Divers itself sort of brought me towards the Navy.

Recruits join the organisation with a realistic expectation, borne from the media and interaction with people in the organisation. Thus, from a retention perspective, having built this psychological contract with the recruits and a realistic expectation of what lies ahead, the key for the organisation is to deliver on this, and it does:

AS3, explained that he formed his image of recruit training from his grandfather, a former enlisted sailor and stated that;

[I]t was exactly what I expected it to be. I looked it up online as well and so that helped".

This was supported by AS2 who recalled that;

[I] actually loved recruits, that's one of the reasons I enjoyed was the physical side of it, loved the training side of it, I genuinely did. It was the way I expected it to be, demanding enough to be fair.

Many indicated high levels of overall satisfaction throughout recruit training. Both AS3 and AS4 who were both in the same recruit class stated;

I loved recruits as well. To be fair if I could go back again I would. To see the military side of it and the difference to what I ever did before. I mean obviously there was tough days like the fitness side of it where you're up early at six o'clock and so forth.

This sentiment was supported by AS4;

But you were together and had the craic. So even if it was a hot rotten day and you were beasted out on a run with instructors roaring at us, someone always made a joke and lifted the spirits.

What was evident to the author from the interviews conducted was that, although communication from the organisation to the recruits forming clear expectations of recruit training was limited, the expectations which had been formed as a result of information gleaned from friends, family and the media in general created a realistic expectation of basic recruit training resulting in high levels of satisfaction. However, this was a very different experience for the participants when they were posted to sea for the first time.

\section{Expectations of going to sea}

Having established that expectations had been met at the recruit training stage, the natural next step was to explore the interviewee's experiences at sea following completion of branch training and recruit training. It must be stated that, in the opinion of the author and supported by the interviews, the daily aspects of recruit training which consists of basic military training has limited correlation to life at sea, the role these people had been recruited to fulfil. 
The DF, in the findings of the Well Being in the Defence Forces climate survey published in 2015 acknowledge the need to meet the expectations of its personnel, stating that "Personnel who feel that their expectations are being met display a greater commitment to the organisation" (Irish Defence Forces, 2015, p.84).

Having asked the interviewees about their expectations of life at sea, and how it correlates with reality, a clear pattern emerged. AS2 stated simply;

I was a bit ready, but nothing prepares you for sea until you go to sea, like it's different.

AS1 supported this sentiment stating;

Yeah, we did everything on the base and stuff there just like one day on a ship and we couldn't really take much from that right so nobody really knew what was going to happen when you do go on a patrol for the first time.

Some of the misconceptions or lack of knowledge, were particularly worrying to the author such as that described by AS1,

For me, recruit training for us was just physical fitness, arms drill, foot drill was mainly it, physical stuff. We did very little being brought down to the ships on the base and there's very little of that. Even though we did ask, like what branches we want to go to. We thought we'd see more of the ships more as this is where we thought we were going to spend our time. We didn't get that, so we didn't really know.

The fact that life at sea is significantly different to life ashore whilst in recruit training is recognised within the organisation. Bottom line - basic military training has a direct link to life in the Army but has less to do with life at sea in the INS. The INS recognises this and attempts to offset the land component, by sending all recruits to sea on board a ship during their recruit training. The intention is to give them time within each ship's department to give a clear indication of roles on board and daily routines, whilst giving an indication of general conditions experienced at sea. This provides a form of RJP intended to establish an accurate expectation of their future roles on board ship, quashing any misconceptions in the process (Schreuers \& Lescreve, 2001).

However, a common trait emerging from the interviews was sea-time inconsistency within the NS during this RJP. Within the NS this RJP is termed as "sea week", a period dedicated in providing recruits with on-the-job training. Whilst the INS has attempted to make progress in this area and provide a consistent program, this time can vary and is not guaranteed due to the constraints of MDSO and Naval Operations. Unfortunately, these irregularities emerged during interviews. AS2 stated;

I did get the sea week and all that, but you have no idea what it's like, it's still not 100 percent. I suppose it's hard to know what expectations are supposed to be, like I said, I loved recruits I genuinely did but it was basic just Styer, H\&K and marching that was the main thing, but nothing prepares you for sea until you go to sea.

However, AS1's experience was somewhat different and lacked any time at sea, 
There was a ship anchored in Bantry, so we were just transported down by naval transport. Got a rigid inflatable boat (RIB) out to the ship, spent the day while she was anchored, and then five o'clock taken off, go back to the base. So, you could have done the same realistically alongside here in the base.

Many of the participants had different views when it came to their experience and RJP. Some enjoyed it, some felt like they were used to top up numbers on board and were in the way, however, the overarching theme was lack of time on board to give a real impression of life at sea and on-board ship. AS3 states;

When it comes to ship and on-board training recruit training doesn't really stand to you, especially when it comes to four-week rotations and getting used to not seeing families and then no phones or coverage.

This was supported by AS4;

You might get a day at sea doing the work of each branch which is grand but [you're] back after a week. I'm just in from a four-week rotation and I have my duties to do so I won't get home. The sea week doesn't prepare you for that.

The problem is acknowledged by WO Duignam, the highest-ranking Non-Commissioned Officer (NCO), and head of Seaman's Branch in the INS:

No amount of training can prepare you for life at sea. You will either like it or dislike it. NS training is based around DF syllabus and that won't change. It is all down to numbers and ship availability. We don't have the space on ships for all of these people.

There is also the added complexity to qualify INS personnel in manual handling, firefighting on-board, and to complete a personal survival technique (PST) or sea-survival course prior to deploying to sea which adds to training time. Additionally, the time set aside for this sea acquaint is also based on the availability of ships and is not fixed to occur at a set time, for example after the first four weeks of recruit training. Many of the interviewees had completed 50 percent of their training before putting to sea for their RJP. AS2 described his time during his sea acquaintance,

You were put in different jobs each day and then it becomes easier as you're able to talk about things like what they do day on day. I was told that was like the first time in seven years that they've done that. I think it might have been like the sixth or seventh week, something like that. We had 14 weeks of recruits. So nearly 50 percent through training.

Nonetheless, the information from the interviews all support the case for a longer period on board ship during the sea acquaintance "one day is definitely not enough" (AS1). "You'd probably have to do a patrol" (AS3). At least a three-week patrol to see what it is like" (AS4).

\section{A shift in personal traits of new entrants versus organisational characteristics remaining the same}


Since the upturn in the economy in Ireland, the INS has seen a significant decrease in the number of applicants for recruit training. This is supported by the literature discussed above which identified the effect of perceived job alternative on recruitment and correlates with the experiences of other countries in the Western World during periods of high employment. However, to the credit of the INS, the organisation has succeeded in recruiting a minimum stream continually over the past three years (Irish Defence Forces, 2020). So why has turnover accelerated?

The INS involvement during Operation Pontus, ${ }^{1}$ and subsequently Operation Sophia ${ }^{2}$ rescuing stricken migrants in the Mediterranean, received ample publicity, both though social media, and through the RTE documentary "The Crossing" in 2016. This saw an increase in recruitment over a three-year period, from 57 recruits in 2017 to 102 in 2019 . The positive knock-on effects led to an increase in the number of young people wanting a life less ordinary. Interestingly, many of these young people who commenced training were holding third level academic and trade qualifications. Therefore, the issue for the INS is not recruitment but in fact retention. The challenge for the organisation is keeping these qualified, experienced individuals interested.

According to the Officer in Charge (OiC) of the INS Personnel Management Section (PMS) Commander Frank O'Connor,

Enlisted personnel are clearly the largest rank cohort in the NS. More importantly, they are the hands-on practitioners of many naval skills. Afloat, they are critical in carrying out the operational tasks required of a ship; ashore, they provide an important pool of labour and staff stores and offices throughout the Naval Base in support of the fleet.

Regardless of the qualifications or experience people now have on entry the job of a seaman has remained the same. According to WO Duignam,

Able Ratings are the backbone of the NS. Without Ratings there is no ships company. If NS command wish to complete NS operations the need for Ratings is vital. The often-pitched upside to the job is the operational role that seamen play on board ship they are in the exciting end of it. They are the guys out driving the boats. They are the operational people, firing the ship's weapons. They are the ones that steer and drive the ship.

AS4 supports this image by stating,

I was asked by the lads why did I choose to be a Seaman when all I'll be doing is cleaning all the time. I became a Seaman to drive ribs and fire weapons. I don't mind the cleaning, but I hate cleaning for the sake of it when it could be more beneficial to do seamanship training.

Nonetheless, most of the interviewees were uncertain about their future in the NS. None could commit to service beyond five years, and two had applied for discharge. Many

\footnotetext{
${ }^{1}$ Operation Pontus was the bilateral agreement between Italy and Ireland to aid Migrants in the Mediterranean Sea.

${ }^{2}$ Operation Sophia was the EU mandated Common Security and Defence Policy (CSDP) mission on Arms interdiction, oil smuggling and people trafficking in the Mediterranean.
} 
have stated that, should they not be successful in applying for a trade or a transfer to another division before their contract expired, they would seriously consider leaving the INS. AS5, a college graduate, joined the service to see the world, meet new people and participate in operations like Operation Sophia. He had yet to deploy on an overseas mission and is unlikely due to the termination of Operation Sophia. He has applied for discharge from the service stating;

We were told we were going to the Med but that never happened. Many lads were looking forward to that and the extra money. I can see Ireland anytime, I wanted to be a part of something different. I won't just down tools, I'll weigh up my options before I go, but we were promised missions.

When asked if one of the many measures to improve retention being sought is to get our ships back into missions like Operation Sophia OiC PMS replied;

Yes, getting ships back into the business of maritime deployments overseas (PONTUS, SOPHIA, etc.) is an important part of retention. Although I haven't been, the discussions I've had with people of many ranks have all demonstrated that they felt this was the height of their professional career. It demonstrates to people what all their training has been about and how it can be used in a very different context to the normal MDSO work in the Irish Area of Operations. The NS is already struggling with retention and has been for some time now, so these missions are important.

AS6 is from Derry and is a qualified chef. Uncertainty within his career prospects and not meeting his expectations have been key influences in his decision to leave the NS. He is very disgruntled with the service stating;

I joined for excitement after seeing the lads in the Med. I also wanted to be a part of the armed boarding team which I saw advertised on the television, which I am. But we've only put the gear on a few times and been to the pistol range once this year. It's a joke if you want me to be able to shoot someone in the leg at sea with such little practice. We can't defend ourselves never mind the State.

He goes on to say;

I wanted to be a Radio Repair Technician (RRT) but there were no trades. That was my main reason for joining. I'll apply to the fire service in Scotland and see how that goes. At least I'll be closer to home as there's nothing down here for me.

AS6 is 20 years of age and a year through his first two-year sea rotation with a further year and a task book to complete before being considered for a Technical Trainee Scheme (TT Scheme). Furthermore, it will be three to four years before he can expect to be selected for an NCO course. He is looking to "Strengthen the Nation" or the "Life Less Ordinary" promised to him. The question for him is what can he move on to without a definitive plan? Can the organisation meet the expectation of the higher educated and better qualified entrants now entering the organisation? Or is the fallout from retention issues affecting the QOL to maintain a career and remain in the NS?

\section{Quality of life of those remaining}


A key finding of the DF 2015 climate survey was related to the work life balance for retention strategy. "Where an individual is having issues with regard to work life balance this will negatively affect their overall satisfaction with life and their satisfaction with military life" (Defence Forces, 2015, p.30) However, the increase in turnover is having a greater effect on the QOL of those remaining within the organisation. WO Duignam elaborated on this during his interview,

The establishment for Able Seaman in the INS is 164, the current strength is 90 . We have a short fall 70. This establishment is based on the current CS4 structure for seven ships. We are operating nine ships. The workload for Able Seaman is too much. This is not just the case for personnel at sea but also in shore-based appointments. AS1 explains how the shortfall of personnel is having an effect;

I know lads on the base getting back-to-back duties, it nearly broke them. They found it very unfair and they found it like you're literally, you're going to work, you're going to bed, you're going to work you're going to bed. Your body cycles completely ruined.

Many of the interviewees also found it difficult to avail of rest and relaxation (R\&R), time allotted to them on completion of a four-week period at sea on MDSO. AS4 emphasised the point;

There's still duties to do, medicals and fitness tests which can only be completed on certain days when we get back, so we end up supporting the base not them supporting the ships. I try to plan my duties days so I can restoff and have a day's R\&R so I can travel home. It doesn't always work out like that.

Typically, ships will carry out four weeks at sea on MDSO followed by a period alongside the Naval Base (NB) of two weeks. During this downtime period a ship will be required to be replenished, maintained, and kept secure, meaning that many enlisted sailors can complete two 24-hour duties on board per week. This means another four days away from home. Although this may not seem excessive, for many it affects their QOL and relationships are strained at home. However, many young sailors live on board the ship on completion of MDSO. Therefore, they have no escape from their place of work where many find it difficult to sleep or rest during a working day. This is due to a severe lack of accommodation that is available on the Naval Base where all rooms are filled with existing personnel.

\section{Lack of accommodation affecting quality of life}

During the interview process a collective theme developed regarding accommodation on the Naval Base. Of the eight sailors interviewed seven lived on-board their ships, which, as stated earlier, is also their place of employment. AS2 was living on board the L.E. CIARA, which is the smallest ship in the fleet, and when at sea shared his accommodation with 10 other men. This number reduces on completion of MDSO. However, this cramped accommodation is not suitable for daily living. AS2 has sought accommodation on the Naval Base but there are no vacant rooms. When asked if there was accommodation available would he live there, his reply was; 
I'd take it in a second. I suppose it's just handier, it could be cost saving as well that would be a factor, but just so much handier. Everyone in my class is living in on board the ships like with exception of literally one.

Commander O'Connor supports this sentiment when asked if QOL has an impact on retaining enlisted personnel?

Certainly. Again, that comes down to factors like accommodation, internet access at sea.

For many of the young sailors, living on-board is a necessity as paying for rent and a car is unsustainable. Therefore, many choose a car as it provides them with the freedom to leave the Naval Base. To put this into context the Naval Base is an island in Cork Harbour with one access bridge. It is in fact quite distant from Cork city centre. The closest adjacent village is Ringaskiddy, with few attractions or amenities to entertain a young man or woman. A small passenger boat runs at specific times during the day to and from the town of Cobh, however, to use this and public transport requires a day of planning, logistics and time.

\section{The effects of low pay on QOL}

Job security should be a strong incentive for retention under any economic conditions, but particularly in uncertain times, even if basic pay is deemed low. The sentiment of job security was common with many participants. However, allowances such as patrol duty allowance (PDA) for new seaman is proving an issue. PDA is an extra allowance for sailors at sea. When the interviewees were asked to identify their main source of dissatisfaction with the INS at present, matters concerning their sea pay came to the fore. All the interviewees had concerns with the high level of taxation on their PDA and many felt that this, as a tax-free allowance, was an easy fix for retention. AS1 clarified this by stating;

So for me, one of the biggest shocks was when I opened up my first patrol PDA and saw what I got and what I was taxed. Especially earning so little. Everyone I talked to seem to be basic pay was alright, duties there was a bit of an issue there, but it was always about PDA. Everyone I talked to, and it was kind of along the same lines that just don't tax it. Keep it tax exempt. You would have trouble getting lads off ships. Ships will have numbers because of the PDA.

AS3 and AS7 both made comparisons to friends serving in the army and their allowances. They felt that the government was unfairly treating INS personnel who put to sea on average for eight months of the year, where a soldier could earn a tax-free allowance serving overseas for six months on a United Nation mandated mission. AS6 argued the case further emphasising;

The army go to the Leb [Lebanon] for six months and earn enough money for a new car or down payment for a house. We're here doing the domestic work and getting our pay hacked. There's also a maritime mission in the Leb that the navy could be involved in. How come the department or government haven't sent us there instead of the Med.

This research identified studies where Naval personnel specifically, experiencing work family conflict, have shown no greater dissatisfaction with their jobs suggesting that a career in the Navy involves acceptance of long hours and periods of separation from family (Capon, 
et al. 2007). Nevertheless, seven interviewees said that "this was a single person's life" and they could not comprehend how serving members with children and mortgages could afford to survive. AS1 has a partner and young son and is living outside of the NB. His income must be supported by the Housing Assistance Payment Scheme (HAP) and he feels both the pressure financially and from his partner to seek a better paid job. He stated;

My partner is turning the screw, when you going to leave, because the pressure she has to raise a small child on her own when I'm at sea. We're both from Kerry and our families, so she doesn't really have anyone to lean on here. She doesn't drive. She's been finding it a bit tough when I go to sea, raising a small toddler. She doesn't have a break and so she's venting and I'm feeling the pressure. It doesn't help when your pay is low after being away for four weeks.

Several reiterated that they personally could not afford to pay rent, have a car and or children, and that was why many had to live on board. Commander O'Conner stated when asked if the current rates of pay were factors in retention, "[f]or Able Rates, the poor pay is certainly a factor, perhaps they key factor". This is a reality for many serving personnel. Unfortunately, of the eight participants, seven stated they cannot afford the quality of life living outside of the NB on their current wage.

\section{The role of shocks in retention}

The identification of the "unfolding model" of voluntary turnover and unexpected life events, known as shocks, can cause voluntary turnover. When asked if unexpected life events would affect their decision to remain in the service, six of the eight participants unequivocally answered "yes" without a second thought. One was uncertain, and the final one had to think of job security. AS3 is from the midlands and clarified, "[i]f anything happened my parents I'd be gone in the morning".

This was a shared view of the participants when it came to life jarring events such as unplanned pregnancy, loss of a loved one, changes in relationship status and unsolicited job offers. These areas are a critical requirement of any exit survey or questionnaire. Commander $\mathrm{O}^{\prime}$ Connor is acutely aware of previous exit surveys conducted in INS where life shocks are not catered for, nor come into the equation. Predominately it has been about the QOL. He confirmed that, "[a]necdotally, most of the exit interviews do show unwillingness to put up with seagoing as a big factor, along with pay".

Shocks are powerful antecedents for turnover and retention and if categorised into exit interviews they may provide insight into how the organisation might respond to future personal or organisational shocks. When asked during his interview does he see himself staying in the INS or leaving some time in the future AS6 replied;

From what I hear, nobody has the intention of being here for five years. Most people have the intention of being gone before [five years]. Because there is an aspect that people look at like "if I leave what am I going to do". That is the only reason why a lot of people are still here.

Retention is an issue already impacting on the operational capability of the INS. However, as stated in the findings, there are still several improvements that can be made to increase job satisfaction, organisational commitment, and overall retention rates. 
Firstly, there is an urgent requirement to put a retention strategy in place to stem the flow of young, enlisted personnel from the INS. Secondly, the organisation must address the quality-of-life issues resulting from the shortage of Seaman's Branch personnel and concerns regarding pay in the service. Thirdly, the INS must manage the psychological contract aspect of first-time seafarers utilising realistic job previews at the earliest stage available during recruit training to reduce financial wastage caused by training personnel with no aptitude for seagoing life. Fourthly, the organisation must either manage the expectations of the new higher qualified new entrants into the organisation or target entrants with lesser qualifications. Finally, the organisation should seek to distribute work details evenly throughout the ship fostering a togetherness attitude on-board rather than an "each division to its own mentality".

\section{PART FOUR. Conclusions and Recommendations}

From the outset the importance of this research was identified to the organisation. It was clear that retention was an issue for the INS, with several preconceptions regarding the causes of voluntary turnover within the organisation. The findings are clearly linked to previous research undertaken by Sumer \& Van de Ven (2007) in their 'Proposed Model of Military Turnover', and the similarities are striking. Their evidence suggests the existence of different dynamics for military withdrawal, as well as the importance of individual differences and factors other than attitudes in military turnover. This coincides with many of the key findings of this paper with regards to shocks, QOL perceptions, the requirement for INS specific exit survey, and retention strategy. However, different to Sumer \& Van de Ven (2007), a key finding in this research relates to the management of expectations, and the psychological contract are RJP's.

The findings indicate that the RJP need to be realistic. Individuals should have a clear appreciation of their future role at sea at the earliest opportunity in their recruit training. The reality of life at sea must be made clear to all new recruits before they qualify prior to posting to sea. RJP's may not reduce overall retention rates however, they will considerably reduce the burden of training individuals who have little or no aptitude for seagoing duties. This should be a priority, the INS must eliminate the risk of unmet expectations by ensuring that the RJP is accurate, realistic, and utilised at the earliest possible opportunity.

The INS does not have a retention strategy. The research leads to the conclusion that the organisation needs to develop strategies for retention in the short term. Pay and allowances continue to be key issues for new entrants where increases cannot be guaranteed. Moreover, the organisation cannot rely on recruitment as the sole strategy for maintenance of numbers. The findings clearly illustrate that the INS now needs to develop a retention strategy for young enlisted personnel. These research findings could provide a foundation on which the INS could build a retention strategy. Nevertheless, it is evident that the starting point for any retention strategy is the requirement to identify and understand the issues being felt by new enlistees to the organisation. The key to this is an integrated personnel management system which can collect this data, identify solutions where applicable, and finally, communicate the need and method for changes to higher command.

It has been identified that current high rate of turnover is having an impact on the operational capability of ships (O'Riordan, 2019). The findings of this research demonstrably show that current turnover rates are having a direct bearing on those that remain in the organisation. These sailors must be prioritised in any retention strategy. Caring should take 
the form of enhanced support for personnel and their dependents, particularly those separated from family for prolonged periods due to the exigencies of the service (Irish Defence Forces, 2002). Strategies exploring the reduction of shore duties for seagoing personnel must be examined. It is acknowledged that operational commitments may in certain situations result in difficult decisions. This is the reality of life in the military. However, communicating the realities of the situation should be utilised to ensure that, as far as reasonably possible, the effect on perceived organisation support is minimised.

This research identifies the diverse nature of shocks and how different shocks affect voluntary turnover. Shocks are influential precursors for turnover and may provide insight into how the INS could defuse their affects to stem the tide of turnover. The strengths of this research are that the three main themes identified are worthy of individual research alone. However, having identified three themes pertaining to turnover and retention, these findings afforded a more complete understanding of the problem to the INS.

Several recommendations arise from this paper. The INS should create a retention strategy team from within the branch to communicate with personnel serving at sea, identify the issues, and explore opportunities for improvement or change. Based on the findings of this research, for change to occur and gain traction, the problems must be identified and dealt with primarily within the branch. The sea acquaintance which takes place during the recruit training phase should be increased to a full four-week patrol to ensure a realistic expectation of seagoing life is experienced. Finally, INS QOL initiatives should be reviewed considering current turnover rates to ensure that they are meeting the needs of the people left within the Seamen's Branch.

Please note that the views expressed in this article are those of the author alone and should not be taken to represent the views of the Irish Defence Forces, the Command and Staff School or any other group or organisation.

\section{BIBLIOGRAPHY}

Agho, A. O., Mueller, C. W., \& Price, J. L. (1993). Determinants of employee job satisfaction: An empirical test of a causal model. Human relations, 46(8), 1007-1027.

Ajzen, I. (1985). From intentions to actions: A theory of planned behavior. In J. Kuhi \& J.Beckmann (Eds.), Action control: From cognition to behavior (pp. 11-39) (pp. 11-39). Heidelberg: Springer.

Allen, D. G., Shore, L. M., \& Griffeth, R. W. (2003). The role of perceived organizational support and supportive human resource practices in the turnover process. Journal of management, 29(1), 99-118.

Argyris, C. (1960). Understanding organizational behavior. Homewood, Illinois: Dorsey Press.

Beach, L. (1990). Image theory: Decision making in personal and organizational contexts. New Jersey: Wiley \& Sons Inc.

Bertrand, F., Schreurs, B., Lescreve, F. J., Hansez, I., \& De Keyser, V. (2006). Measuring a conceptual model of military turnover. Liege, Belgium: Proceedings of the International Military Testing. 
Bosman, J., Buitendach, J.H., \& Rothmann, S. (2005). Job insecurity, burnout and work engagement: The impact of positive and negative affectivity. South African Journal of Industrial Psychology, 31(4), 48-56.

Britt, T. W. In H. J. Langholtz. (1998). Psychological ambiguities in peacekeeping, The Psychology of Peacekeeping (pp. 111-128). Westport: CT: Praeger.

Britt, T. W., \& Adler, A. B. (1999). Stress and health during medical humanitarian assistance missions. Military Medicine, 164, 275-279.

Bryce, M. (2009). The Unique Nature of Military Service. Canberra: Australian Defence Force Welfare Association.

Bryman, A. (2012). Social research methods (4th ed.). London: Oxford Press.

Capon, J., Chernyshenko, O. \& Stark, S. (2004). Applicability of Civilian Retention Theory in the New Zealand Military. Retrieved Sept 19 10, 2019, from

http://citeseerx.ist.psu.edu/viewdoc/download?doi=10.1.1.570.550

Carsten, J. M. \& Spector, P. E. (1987). Unemployment, job satisfaction, and employee turnover: A meta-analytic test of the Muchinsky Model. Journal of Applied Psychology, $3(72), 374-381$.

Cassell, C. \& Symon, G. (2004). Essential Guide to Qualitative Methods in Organisational Research. London: Sage.

Cook, W.S, Fleps, W, Lee, W \& Mitchel, T. (2007). The psychology of voluntary employee turnover. Current Directions in Psychological Science, 16(1), 51-54.

Deely, G. (2014). Great Expectations: The Effect Of Organisational Change On The Psychological Contract Of Enlisted Personnel In The Defence Forces. Kildare: Irish Defence Forces.

Deepa, V. (2016). Psychological Contract and Employee Behaviour. International Journal of Research in Social Sciences, 6(9).

Donnelly, D.P., \& Quirin, J. (2006). An Extension of Lee and Mitchell's Unfolding Model of Voluntary Turnover. Journal of Organizational Behavior, 27, 59-77.

Dowden, C. (2000). Quality of life in the Canadian Forces: Conceptualization and measurement of the QOL construct. Ottawa, Canada: CF Director Human Resources Research and Evaluation, National Headquarters.

Easterby-Smith, M., Thorpe, R. \& Jackson, P. (2008). Management Research (3rd ed.). London: Sage.

Feldman, D. C. (1977). The Role of Initiation Activities in Socialization. Human Relations, 30(11), 977-990.

Flick, U. (2007). Managing Quality in Qualitative Research. London: Sage.

Ford M.T, Gibson J.L, Decesare A.L, Marsh S.M, and Griepentrog B.K. (2013). Pre-Entry Expectations, Attitudes, and Intentions to Join Predict Military Tenure. American Psychological Association, 25(1), 36-45. 
Gauger, J. W. (2001). "Integrating Content and Process Models to Study Turnover in the Canadian Forces". New Jersey: University of New Brunswick.

Gerhart, B. (1990). Voluntary turnover and alternative job opportunities. Journal of Applied Psychology, 5(75), 467.

Gibbs, G. R. (2007). Thematic coding and categorizing. Analyzing Qualitative Data. London: Sage.

Godlewski, R \& Kline, T. (2012). A Model of Voluntary Turnover in Male Canadian Forces Recruits. Military Pyschology, 24, 251-265.

Griffeth, R. W., \& Hom, P. W. (2001). Retaining Valued Employees. New York: Sage Publications.

Griffeth, R.W., Hom, P.W. \& Gaertner, S. (2000). A meta-analysis of antecedents and correlates of employee turnover. Journal of Management, 29, 436-488.

Gurbuz, S. (2009). Some possible antecedents of military personnel organizational citizenship behaviour. Military Psychology, 21(2), 200-215.

Hall D.T, \& Moss J.E. (1998). The new protean career contract: helping organizations and employees adapt. Organizational Dynamics, 26(3), 22-37.

Heffernan, M. \& Rochford, E. (2017). Psychological contract breach and turnover intention: the moderating effects of social status and local ties. Irish Journal of Management, 38(2), 99-115.

Hogue, L. (2006). A comparison study of the major factors affecting employee retention in the U.S. Army and Corporate America.From Science to Solutions. Science Application International Corporation.

Holt, D. T., Rehg, M. T., Lin, J. H., \& Miller, J. (2007). An application of the unfolding model to explain turnover in a sample of military officers. Human resource management, 46(1), 35 49.

Holtom, Brooks \& Mitchell, Terence \& Lee, Thomas \& Inderrieden, Edward. (2005). Shocks as causes of turnover: What they are and how organizations can manage them. Human Resource Management, 44, 337-352.

Hosek, J. R. \& Totten, M. (2002). internationalmta.org. Retrieved February 09, 2020, from http://www.internationalmta.org/Documents/2004/204007P.pdf

Irish Defence Forces. (2015). The White Paper on Defence. Dublin: Defence Forces Printing Press.

Irish Defence Forces. (2015). Well Being in the Defence Forces. New Bridge, Co Kildare: Irish Defence Forces.

Irish Defence Forces. (2020). Naval Service General Enlistment. Haulbowline, Co. Cork.

Johnson, J. L., \& O'Leary-Kelly, A. M. (2003). The effects of psychological contract breach and organizational cynicism: Not all social exchange violations are created equal. Journal of Organizational Behavior, 24(5), 627-647. 
Judge, T \& Mueller, J. (2012). Job Attitudes. Annual Review of Pyscology, 63, 341-367.

Kabasakal, H., Dastmalchian, A., \& Imer, P. (2011). Organisational citizenship behaviour: A study of young executives in Canada, Iran, and Turkey. The International Journal of Human Resource Management, 22(13), 2703-2729.

Kerce, E. (1995). Quality of life in the U.S. Marine Corps. United States Navy Personnel Research and Development Center, 95(4).

Krackhardt, D. (1992). 'The strength of strong ties:The importance of Philos in organizations. In H. U. Press (Ed.), Structure, Form and Action (pp. 216-239). MA: Cambridge.

Lee.W, \& Mitchell. T. (1994). The Unfolding Model of Voluntary Employee Turnover. The Academy of Management Review, 19(1), 51-89.

Levinson, H.; Munden, K. J.; Price, C. R; Solley, C. M. (1962). Men, management and mental health. Cambridge. MA: Harvard University Press.

Mano, O. (1994). The Differences between Barnard's and Simon's Concepts of Organization Equilibrium-Simon's Misunderstanding about Barnard's Intention. Economic Journal of Hokkaido University, 23, 13-28.

McDermott, A.M., Conway, E., Rousseau, D.M. and Flood, P.C. (2013). Promoting effective psychological contracts through leadership: The missing link between HR strategy and performance. Human Resource Management, 2(52), 289-310.

Meyer, J.P., \& Allen, N.J. (1997). Commitment in the Workplace. Theory, Research and Application. Thousand Oaks, CA: Sage.

Miles, D.E., Borman, W.E., Spector, P.E., \& Fox, S. (2002). Building an integrative model of extra role work behaviours: A comparison of counterproductive work. International Journal of Selection and Assessment, 10(1), 5-11.

Mitchell, T., Holtom, B., Lee, T., Sablynski, C and M. Erez. (2001). "Why People Stay" Using Job Embeddedness to Predict Voluntary Turnover. Acedemy of Management Journal, 44, 1102-1121.

Mobley, W. H. (1977). Intermediate linkages in the relationship between job satisfaction and employee turnover. Journal of Applied Psychology, 62, 237-240.

Mobley, W., Horner, S., \& Hollingsworth, A. (1978). An evaluation of precursors of hospital employee turnover. Journal of Applied Psychology, 63(4), 408-414.

Morrell, K., J. Loan-Clarke \& Wilkinson K. (2001). Unweaving Leaving: The Use of Models in the Management of Employee Turnover. Business School Research Series, 1-65.

Morrison, E. W., \& Robinson, S. L. (1997). When employees feel betrayed: A model of how psychological contract violation develops. Academy of Management Review, 22, 226-256.

Mowday, Richard T., Christine S. Koberg and Angeline W. McArthur. (1984). "The Psychology of the Withdrawal Process: A Cross-validational Test of Mobley"s Intermediate Linkages Model of Turnover in Two Samples". Academy of Management Journal, 27(1), 79-94.

Mumford, E. (1991). Job satisfaction: a method of analysis. Personnel Review, 20(3), 11-19. 
Organ, D. W. (1988). Organizational citizenship behavior: The good soldier syndrome. (1st ed.). MA: Lexington.

O'Riordan, S. (2019, june 28). www.irishexaminer.com. Retrieved Dec 30, 2019, from https://www.irishexaminer.com/breakingnews/ireland/two-naval-vessels-docked-due-toongoing-personnel-challenges-933471.html

Price, J. L. (1977). The Study of Turnover. Ames, IA: Iowa State University Press.

Price, J. L. and Mueller, C.W. (1986). Absenteeism and Turnover among Hospital Employees. Greenwich: JAI, Press.

Robinson, S.L. and Rousseau, D.M. (1994). 'Violating the psychological contract: Not the exception but. Journal of Organisational Behaviour, 15(3), 245-259.

Rousseau, D. M. (1995). Psychological contracts in organisations: Understanding written and unwritten agreements. Thousand Oaks: Sage.

Rousseau, D. M. \& Wade-Benzoni, K. A. (1995). Changing individual-organizational attachments: A two-way street. In The changing nature of work (In A. Howard (Ed.), The changing nature of work. ed., pp. 290-321). San Francisco: Jossey Bass.

Rousseau, D. M. (1989). Psychological and implicit contracts in organisations. Employee Responsibilities and Rights Journal, 2, 121-139.

Rurkkhum K.R, \& Bartlett. S. (2012). The relationship between employee engagement and organizational citizenship behaviour in Thailand. Human Resource Development International, 15(2), 157-174.

Samad, S. \& Yusuf Y.S. (2012). The Role of Organizational Commitment in Mediating the Relationship between Job Satisfaction and Turnover Intention. European Journal of Social Sciences, 1(30), 125-135.

Schein, E. H. (1980). Organization Psychology. Englewood Cliffs, New Jersey: Prentice-Hall.

Schneider, B. (1987). The People make the Place. Personnel Psychology, 40(3), 437-453.

Schreurs, B., \& Lescreve, F. (2001, Dec 10). Voluntary Turnover in the Belgian Army: Unmet Expectations and the Role of Information Provision. Belgium: Belgian Armed Forces Personnel Division. Retrieved from Accessed at http://www.iamps.org/pdf/schreurs.pdf on.

Schwartzman, H. (1993). Ethnography in Organisations. London: Sage.

Sechudi, O. O. (2014). The relationship between transformational leadership and organisational citizenship behaviour. Pretoria: University of South Africa.

Sharma, L. (2015). Process Models of Employee Turnover during 1975-1995: A Review. European Academic Research, 3(15), 2494-2518.

Singh, B. (2019). editage.com. Retrieved February 7th, 2020, from https://www.editage.com/insights/importance-of-research-ethics

Singh, N \& Sharma L.S. (2015). Process Models of Employee Turnover during 1975-1995: A Review. European Academic Research, 3(2). 
Singh, N. (2015). Process Models of Employee Turnover during 1975-1995: A Review. European Academic Research, 2(3).

Steers R. M., \& Mowday R. T. (1981). Employee turnover and the post decision accommodation process. Research in organizational behavior, 3 .

Sumer, H. (2004). A Model of Military Turnover. Brussels, Belgium: Paper presented at the 46th Conference of the International Military Testing Association.

Sumer, H. C., \& Van de Ven, C. (2007). A Proposed Model of Military Turnover. Brussells: NATO.

Sumer, H.C., \& Van de Ven, C. (2007). A Proposed Model of Military Turnover. Brussels: Paper presented at the 49th Conference of the International Military Testing Association.

Tekleab, A.G, \& Chiaburu, D. (2011). Social Exchange in the Workplace: An Empirical Examination of Form and Focus. Journal of Business Research, 64, 460-466.

Tsai, Y., \& Wu, S.W. (2010). The relationships between organisational citizenship behaviour, job satisfaction and turnover intention. Journal of Clinical Nursing, 19(23), 3564-3574.

Tyler, D. (2016). Make Morale Our First Priority. The United States Naval Institute, 142(11).

Van de Ven, C. (2003). The drop-out rate during training: In line with expectations? Holland: Behavioral Sciences Division, The Royal Netherlands Army.

Van Dyk, J., \& Coetzee, M. (2012). Retention factors in relation to organisational commitment in medical and information technology services. SA Journal of Human Resource Management, 10(2), 433-444.

Warn, J. (1994). Factors Influencing the Turnover of Skilled Personnel: A Case Study. Pacific Journal of Human Resources, 32(1), 29-40, 32(1), 29- 40.

Weiss, H.M., MacDermid, S.M., Struss, R.,Kurek, K., Lee, B, \& Robbins, R. (2003). Retention in the Armed Forces : Past Approches andNew Directions. Military Family Research Institute, 239.

Wilcove, G.L., Schwerin, M.J., \& Wolosin D. G. (2003). An Explanatory Model of Quality of Life in the U.S Navy. Military Psychology, 15(2), 133-152.

Will, T. (2012). Enlightenment political philosophy and organizational Citizenship behaviour: Contextualizing historical discourse. Management \& Organizational History, 7(4), 285-302.

Yoon, C. (2009). The effects of organizational citizenship behaviours on ERP system success. Computers in Human Behaviour, 25(2), 421-428.

Zhang, D. (2011). Organisational Citizen Behaviour. PSYCH 761 White Paper.

Zimmerman, R.D, Swider, B.W \& Boswell, W.R. (2019). Synthesizing content models of employee turnover. Wiley Human Resource Management, 114, 58-99. 